\title{
Psychologiczna koncepcja poszukiwania sacrum w religijności i duchowości
}

Interesującym zjawiskiem społecznym, zataczającym coraz szersze kręgi w społeczeństwach postmodernistycznych, jest rozdźwięk między religijnością a duchowością. W przeszłości religia i religijność były nieodłącznie związane z duchowością, co odzwierciedlały szkoły życia duchowego, rozwijane w ramach tradycji religijnych, np. szkoła ignacjańska w Kościele katolickim, szkoły duchowości w buddyzmie czy sufizm w ramach islamu. Obecnie, szczególnie w krajach cywilizacji zachodniej, można spotkać wiele osób, które interesują się problematyką duchowości i posiadają głębokie życie duchowe, lecz jednocześnie nie przynależą do żadnej z powszechnie uznanych religii. Ich postawa życiowa charakteryzuje się aktywnością mającą na celu rozwój duchowy, która odbywa się poza tradycyjnymi religiami czy wyznaniami. W ostatnich latach zjawisko duchowości stało się przedmiotem bliższego zainteresowania psychologii, co znajduje oddźwięk we wzrastającej liczbie publikacji z zakresu psychologii religii osobowości i zdrowia ${ }^{1}$.

Celem niniejszego artykułu jest ukazanie zjawiska poszukiwania sacrum w ramach religijności i duchowości z punktu widzenia współczesnej psychologii oraz wyjaśnienie specyfiki obydwóch fenomenów pod kątem sacrum. Prezentowane treści wskażą także na charakterystyczne cechy poszukiwania sacrum $\mathrm{w}$ religijności i duchowości oraz czynników determinujących te dążenia.

\footnotetext{
${ }^{1}$ Por. M. Good, T. Willoughby, The Role of Spirituality Versus Religiosity in Adolescent Psychosocial Adjustment, ,Journal of Youth and Adolescence” 35 : 2006, nr 1, s. 39-40; J. D. Kidd, T. M. Witten, Understanding Spirituality and Religiosity in the Transgender Community: Implications for Aging, „Journal of Religion, Spirituality and Aging” 20 : 2008, nr 1-2, s. 30-32; S. D. Kilpatrick, A. J. Weaver, M. E. Mccullough, Ch. Puchalski, D. B. Larson, J. C. Hays, C. J. Farran, K. J. Flannelly, A Review of Spiritual and Religious Measures in Nursing Research Journals: 1995-1999, „Journal of Religion and Health" $44: 2005$, nr 1, s. 55-57.
} 


\section{Obecność sacrum w religijności i duchowości}

Precyzyjna analiza historyczna życia społecznego prowadzi do wniosku, że religijność i duchowość od wielu wieków są częścią ludzkiego doświadczenia, i to nie tylko na płaszczyźnie stricte religijnej, lecz także i kulturowej, społecznej czy politycznej. Elementy religijne i duchowe są odnajdywane w dziełach muzyki, sztuki, poezji, ruchów społecznych, prądów politycznych, moralności itd. Religijność i duchowość są badane z perspektywy wielu nauk (religiologii, filozofii, teologii, psychologii), które oferują nieco różne sposoby rozumienia tych pojęć i wzajemnych relacji między nimi. Od ponad stu lat zagadnienie religijności stanowi przedmiot badań psychologii. Znani psycholodzy, tacy jak W. James, E. Starbuck, G. S. Hall i J. H. Leuba, poświęcili zagadnieniom religijnym wiele miejsca w swoich pracach². Ich zasługą było usystematyzowanie psychologicznych badań nad religią oraz analizowanie powiązań religijności z czynnikami osobowościowymi i społecznymi.

Z uwagi na psychologiczny charakter niniejszej pracy skoncentrujemy się przede wszystkim na analizowaniu religijności i duchowości z punktu widzenia psychologii. Jednocześnie uwzględnione zostaną pewne zagadnienia wyrastające z filozofii czy religiologii, bez których trudno prowadzić dyskurs psychologiczny wymagający rzetelnego ustalenia zakresu pojęciowego stosowanych terminów.

Pierwszym z prezentowanych fenomenów jest religijność. Tradycyjne definicje religijności podkreślają z jednej strony odniesienie do transcendencji, a $\mathrm{z}$ drugiej - związki z wymiarem praktyk i zachowań. Z punktu widzenia psychologii społecznej M. Argyle i B. Beit-Hallahmi określają religijność jako „system wierzeń w boską lub nadludzką siłę, oraz praktyki czci i inne rytuały skierowane do tej siły"3. Istotną cechą prezentowanego rozumienia religijności jest obecność siły (power) zewnętrznej w stosunku do empirycznego świata. Siła ta może być rozumiana jako Bóg, nadprzyrodzoność, Absolut. Charakterystyczną cechą jest wykraczanie poza doświadczalny świat, co nadaje jej wyjątkowy status w sferze ludzkiej. Jednocześnie religijność realizuje się w szeregu praktyk i rytuałów, wykonywanych przez jednostki, które mają na celu podkreślenie indywidualnego zaangażowania religijnego. Analogiczne rozumienie religijności odnajdujemy u D. C. Dollahite’a, który definiuje religijność jako „umowną wspólnotę wiary posiadającą własną naukę i treści, które uwydatniają poszukiwanie świętości (the sacred)"”. W tym ujęciu wyakcentowano wspólnotowy charakter religijności odnoszący się do grupowych praktyk i działań, ukierunkowanych na dążenie do odkrycia świętości.

${ }^{2}$ Por. G. S. Hall, Adolescence: Its Psychology and its Relations to Physiology, Anthropology, Sociology, Sex, Crime, Religion, and Education, New York 1904; W. James, The Varietes of Religious Experience, New York 1902/1961; J. H. Leuba, A Psychological Study of Religion, New York 1912; E. Starbuck, The Psychology of Religion, New York 1899.

${ }^{3}$ M. Argyle, B. Beit-Hallahmi, The Social Psychology of Religion, London 1975, s. 1.

${ }^{4}$ D. C. Dollahite, Fathering, Faith, and Spirituality, ,Journal of Men's Studies” 7 : 1998, nr 7, s. 5. 
We współczesnej amerykańskiej psychologii religii bardzo popularnym określeniem religii jest podejście proponowane przez K. I. Pargamenta, w ramach którego religijność jest rozumiana jako „poszukiwanie znaczenia za pomocą sposobów związanych ze świętością [search for significance in ways related to the sacred]"5. Poszukiwanie świętości bazuje na dążeniu do odkrycia znaczenia na drodze osiągania zamierzonych celów. Dążenie to posiada dynamiczny charakter, który wiąże się z zaangażowaniem i działaniem. Czynnikiem wyróżniającym religijność od innych fenomenów społecznych jest obecność świętości (the sacred), która obejmuje takie pojęcia sił wyższych, jak „Bóg”, „boskość” czy „transcendencja”. Świętość może także oznaczać obiekty posiadające uświęcony status, np. krzyż, uroczystości religijne lub osoby święte.

Odnosząc się do tej propozycji, B. J. Zinnbauer dodaje, że w przypadku religijności poszukiwanie świętości może mieć charakter indywidualny lub społeczny, który rozwija się w ramach tradycyjnego, sakralnego kontekstu ${ }^{6}$. Religijność wyraża zatem osobiste lub zespołowe poszukiwanie przejawów świętości w ramach zorganizowanych i zinstytucjonalizowanych tradycji religijnych. Potwierdzają to badania M. Jarosza, które wskazały obecność zależności pomiędzy odniesieniem do Boga a budowaniem i podtrzymywaniem relacji interpersonalnych ${ }^{7}$.

Interesującą próbę zoperacjonalizowania religijności na rodzimym gruncie polskim przeprowadził C. Walesa, który określając religijność jako osobową i pozytywną relację jednostki do Boga, wyróżnił w jej strukturze osiem podstawowych dziedzin (parametrów) $^{8}$ :

(1) Świadomość religijna - obejmuje pojęcia, przekonania, światopogląd i pozostałe elementy sfery umysłowej związane ze sferą sacrum, które odzwierciedlają intelektualne i rozumowe podejście jednostki do sfery religii; (2) Uczucia religijne - są to czasowo-sekwencyjne i całościowe elementy emocjonalne, które: posiadają pozytywne lub negatywne jakości i intensywność, powstają w sytuacji osobistej i pozytywnej relacji człowieka do Boga oraz stymulują do zachowań o charakterze religijnym9; (3) Decyzje religijne - obejmują preferencje, wybory i planowanie aktywności religijnej, związane z orientacją i kształtowaniem własnego życia w perspektywie religijnej; (4) Więź ze wspólnotą wierzących - reprezentuje społeczny aspekt religijności wyrażający się w nawiązywaniu relacji z innymi osobami; (5) Praktyki religijne - odnoszą się do wykonywanych działań o charakterze religijnym, mających zarówno wymiar indywidualny, jak i wspólnotowy; (6) Moralność religijna - wyrasta

${ }^{5}$ K. I. Pargament, The Psychology of Religion and Coping: Theory, Research, Practice, New York 1997, s. 32.

${ }^{6}$ Por. B. J. Zinnbauer, K. I. Pargament, Religiousness and Spirituality, [w:] Handbook of the Psychology of Religion and Spirituality, red. R. F. Paloutzian, C. L. Park, New York 2005, s. 35.

${ }^{7}$ Por. M. Jarosz, Interpersonalne uwarunkowania religijności, Lublin 2003, s. 207.

${ }^{8}$ Por. C. Walesa, Rozwój religijności człowieka, Lublin 2005, s. 13-14.

${ }^{9}$ Por. tamże, s. 18. 
z przekonania, że na wszystkich szczeblach ludzkiego rozwoju osobisty kontakt z Bogiem stanowi źródło słuszności podejmowanych działań i dostarcza kryteriów moralnych ${ }^{10}$; (7) Doświadczenie religijne - jest to całościowe przeżycie obecności sacrum, w trakcie którego człowiek wchodzi w intencjonalną i pozytywną relację z wymiarem nadprzyrodzonym (Bogiem) ${ }^{11}$; (8) Formy wyznania wiary - odnoszą się w całości do zewnętrznie obserwowalnych zachowań, które wskazują na leżącą $\mathrm{u}$ ich podłoża wiarę religijną.

Dokładne spojrzenie na powyższe dziedziny religijności uwidacznia obecność w nich sfery sacrum. „Nasycenie” sacrum jest różne dla poszczególnych dziedzin. Najsilniejsze wydaje się być w świadomości religijnej, uczuciach religijnych, praktykach religijnych i doświadczeniu religijnym, natomiast słabsze w zakresie decyzji religijnych czy więzi ze wspólnotą osób wierzących. Należy jednak wyraźnie stwierdzić, że praktycznie każda z wymienionych dziedzin religijności wykazuje związek ze sferą sacrum.

Drugim terminem, w ramach którego odkrywamy odniesienia do sacrum, jest duchowość. W przeszłości duchowość rozwijała się głównie w ramach tradycji religijnych i była przedmiotem zainteresowań teologii i filozofii ${ }^{12}$. Współcześnie duchowość stała się fenomenem badanym przez inne nauki, w tym psychologię. Na psychologicznym gruncie duchowość nabrała nieco innego niż dawniej znaczenia i zaczęła reprezentować szersze spektrum doświadczeń. W znanej i często cytowanej definicji D. N. Elkinsa i jego współpracowników duchowość została określona jako „sposób istnienia i doświadczenia, które pojawiają się poprzez świadomość wymiaru transcendentnego i które są charakteryzowane przez określone, identyfikowalne wartości związane z pojęciem ja w ramach szerszego ontologicznego kontekstu"'13. W tym rozumieniu duchowość ujmowana jest jako sposób bycia jednostki będący w relacji do wymiaru pozaempirycznego (sacrum) i jednocześnie związany ze sferą ja. Duchowość jest przejawem psychicznej aktywności jednostki, która aktualizuje się w kontekście uświadomienia sobie obecności sacrum i jego znaczenia dla indywidualnego życia.

W późniejszym czasie D. N. Elkins rozwinął swoją koncepcję duchowości jako fenomen wielowymiarowy, obejmujący sześć zasadniczych cech: uniwersalizm, odniesienie do człowieka, charakter fenomenologiczny, związek ze świętością, obecność „mistycznej energii” oraz współczucie ${ }^{14}$. W tym rozumieniu duchowość jest

${ }^{10}$ Por. C. Walesa, Wyjaśnianie religijności człowieka, [w:] Studia z psychologii w KUL, t. 11, red. P. Francuz, P. Oleś, W. Otrębski, Lublin 2003, s. 32.

${ }^{11}$ Por. C. Walesa, Rozwój religijności człowieka, s. 39.

${ }^{12}$ Por. D. Fontana, Psychology, Religion, and Spirituality, Oxford 2003, s. 11-12.

${ }^{13}$ D. N. Elkins, L. J. Hedstrom, L. L. Hughes, J. A. Leaf, Ch. Saunders, Toward a HumanisticPhenomenological Spirituality: Definition, Description, and Measurement, ,Journal of Humanistic Psychology" $28: 1988$, nr 4, s. 10.

${ }^{14}$ Por. D. N. Elkins, Beyond Religion: Toward a Humanistic Spirituality, [w:] The Handbook of Humanistic Psychology: Leading Edges in Theory, Research, and Practice, red. K. J. Schneider, J. T. Bugental, J. F. Pierson, Thousand Oaks 2001, s. 205. 
zjawiskiem odnoszącym się do całości życia jednostki i wykazującym powiązania z szeregiem cech psychicznych. Doświadczenie duchowe wyraża się w globalnym ustosunkowaniu się człowieka do świata zewnętrznego (ludzie, środowisko przyrody, kosmos), w trakcie którego osoba posiada świadomość obecności świętości i wymiaru pozaempirycznego.

Szerokie ujęcie duchowości na rodzimym gruncie formułuje P. Socha, który określa duchowość jako przejaw typowej psychicznej działalności jednostki postawionej przed egzystencjalnym dylematem ${ }^{15}$. Jest to zatem charakterystyczna cecha stanowiąca jakościowy wymiar procesów psychicznych człowieka.

Socha wyróżnił dziewięć dziedzin związanych z duchowością ${ }^{16}$ : (1) Świadomość i samoświadomość - jest stanem psychicznym, w którym człowiek zdaje sobie sprawę zarówno ze zjawisk wewnętrznych, takich jak własne procesy myślowe, jak i zjawisk zachodzących w środowisku zewnętrznym, np. wydarzenia, relacje $\mathrm{z}$ innymi osobami; (2) Mądrość - odnosi się nie tylko do inteligencji, zdolności twórczych czy typu myślenia, ale obejmuje także umiejętności trafnej oceny i podejmowania decyzji; (3) Uczucia - stanowią nieodłączny element doświadczeń duchowych, gdyż nadają , ,smak i zapach” życiu, stanowiąc emocjonalne źródło przeżyć duchowych ${ }^{17}$; (4) Wrażliwość - można rozumieć ją w znaczeniu racjonalnym - jako spostrzeganie sprzeczności i niejasności informacji; emocjonalnym - jako umiejętność przeżywania siebie i innych osób oraz percepcyjnym - odnoszącym się do zdolności rozróżniania właściwości zmysłowych; (5) Moralność - wyraża się w zdolności rozróżniania dobra i zła oraz posługiwania się kryteriami sprawiedliwości, odpowiedzialności i troski; (6) Twórczość - reprezentuje ludzką zdolność do tworzenia innowacyjnych idei, standardów i wyobrażeń; (7) Poczucie estetyczne-pozwala człowiekowi zaspakajać potrzeby wyższe i znajdywać znaczenie w otaczającym świecie; (8) Światopogląd - odnosi się do spostrzegania świata jako zorganizowanego, hierarchicznego i otwartego systemu wiedzy pochodzącej z różnych źródeł; (9) Religijność - w ujęciu psychologicznym wyraża indywidualną relację jednostki do rzeczywistości transcendentnej (Bóg, Absolut, sacrum); (10) Wiara - jest procesem przekształcania rzeczywistości i jej struktur w ich wewnętrzne odwzorowanie, tak aby można było podtrzymywać przekonania o ich prawdziwości ${ }^{18}$.

Analizując powyższą koncepcję, należy stwierdzić, że reprezentuje ona bardzo szerokie podejście do duchowości rozumianej w kategoriach psychicznej predyspozycji jednostki do doświadczania swojego życia na wszystkich poziomach. Życie duchowe jawi się jako globalna postawa ukierunkowana na rozwój osobisty i społeczny. W ramach tego rozwoju jednostka odkrywa swoje potencjalności

${ }^{15}$ Por. P. Socha, Psychologia rozwoju duchowego - zarys zagadnienia, [w:] Rozwój duchowy człowieka, red. P. Socha, Kraków 2000, s. 17.

${ }^{16}$ Por. tamże, s. 16-17.

${ }^{17}$ Por. tamże, s. 21.

${ }^{18}$ Por. tamże, s. 32. 
i zdolności, stara się przekraczać własne ograniczenia i osiągać coraz to wyższy poziom samoświadomości. Duchowość odnosi się do wszystkich sfer psychiki: poznawczej, emocjonalnej i behawioralnej, dzięki czemu możemy mówić o całościowym charakterze życia duchowego w ramach procesów psychicznych. Pomimo pewnych różnic w porównaniu z wcześniej omówionymi koncepcjami duchowości, podejście P. Sochy zawiera także elementy wspólne, w tym nawiązanie do sfery sacrum, co widoczne jest szczególnie w dziedzinie religijności i wiary.

Obecność sfery sacrum w duchowości podkreśla K. I. Pargament, które twierdzi, że „duchowość jest poszukiwaniem świętości”"19. Świętość zawiera w sobie takie pojęcia, jak „Bóg”, „,boskość”, „Ostateczna Rzeczywistość”, „transcendencja” oraz inne aspekty życia, mające wyjątkowy i niepowtarzalny status dla danych jednostek lub grup. W doświadczeniach duchowych człowiek spostrzega rzeczywistość jako mającą związek ze sferą sacrum, dzięki czemu przeżycia te stają się odróżnialne od innych doświadczeń nie-duchowych. Wydaje się, że związek duchowości ze sferą sacrum jest nieodzowny, jeśli chcemy mówić o określonych formach aktywności jako duchowych.

Porównanie religijności i duchowości jako fenomenów od wieków obecnych w ludzkim doświadczeniu pozwala na stwierdzenie, że centralnym, wspólnym elementem dla obydwóch zjawisk jest ścisłe powiązanie ze sferą sacrum. Pomimo pewnych różnic między religijnością i duchowością (np. formalny i instytucjonalny charakter religijności vs. indywidualność i subiektywność duchowości, związek religijności z tradycją vs. indywidualny rozwój duchowy ${ }^{20}$ ), istnieje podstawowa wspólna cecha, którą jest związek ze sferą sacrum.

\section{Charakterystyczne cechy poszukiwania sacrum}

\section{w ramach religijności i duchowości}

Jak wspomniano powyżej, centralną cechą religijności i duchowości jest odniesienie do sacrum. W tym miejscu nieodparcie nasuwa się pytanie, w jaki sposób można doświadczyć sacrum. Odpowiedź na to pytanie implikuje stwierdzenie, że człowiek poszukuje sacrum, które nie pojawia się automatycznie w sferze myśli i uczuć, lecz wymaga pewnego wysiłku poznawczego. Można zatem mówić o procesie poszukiwania sacrum, dzięki któremu człowiek coraz bardziej buduje swoje relacje do rzeczywistości transcendentnej i jednocześnie pogłębia swoją religijność i duchowość. W ujęciu psychologii religii poszukiwanie sacrum może przejawiać się na dwa sposoby: albo jako profilowanie relacji z Bogiem, albo odkrywanie

${ }^{19}$ B. J. Zinnbauer, K. I. Pargament, Religiousness and Spirituality, s. 36.

${ }^{20}$ Por. W. R. Miller, C. E. Thoresen, Spirituality, Religion, and Health, „American Psychologist” 58 : 2003, nr 1, s. 27-28; J. M. Salsman, T. L. Brown, E. H. Brechting, C. R. Carlson, The Link between Religion and Spirituality and Psychological Adjustment: The Mediating Role of Optimism and Social Support, „Personality and Social Psychology Bulletin” 31 : 2005, s. 523. 
świętości w otaczającej rzeczywistości. W pierwszym przypadku mamy do czynienia z kształtowaniem indywidualnego stosunku do Boga, które odbywa się w oparciu o szereg procesów psychicznych i społecznych ${ }^{21}$. W drugiej sytuacji jednostka poszukuje przejawów świętości w przedmiotach, zdarzeniach i doświadczeniach dzięki spostrzeganym związkom ze sferą sacrum.

Pojęcie „poszukiwania” wydaje się być naczelnym składnikiem religijności i duchowości. Wynika to z rozwojowego charakteru obydwóch fenomenów. Mówiąc o religijności czy duchowości jednostki, mamy na myśli stan, który ulega przemianom na przestrzeni życia ${ }^{22}$. Poszukiwanie sacrum będzie miało zatem dynamiczny charakter. Psychologowie amerykańscy P. C. Hill i K. I. Pargament podkreślają, że religijność jest poszukiwaniem świętości, procesem, poprzez który ludzie chcą odkrywać i być w łączności tym wszystkim, co uważane jest za święte ${ }^{23}$. Poszukiwanie świętości jest równoznaczne z odkrywaniem sacrum i dążeniem do poznania tej tajemnicy.

Z punktu widzenia psychologii motywacji chęć poszukiwania wynika $\mathrm{z}$ faktu, że jesteśmy istotami dążącymi do realizacji celów i chcemy osiągać to, co uważamy za ważne i znaczące w naszym życiu. Proces poszukiwania pociąga za sobą próby odkrywania znaczenia (significance), które oznacza określony zbiór wartościowych, sensownych lub ostatecznych spraw. Mogą one mieć charakter: (1) psychologiczny - bazujący na takich mechanizmach psychicznych, jak wzrost, samoocena, poczucie zadowolenia; (2) społeczny - wyrażający się relacjach interpersonalnych, np. intymność, wsparcie społeczne; (3) fizyczny - odnoszący się do czynników związanych ze zdrowiem lub sprawnością fizyczną oraz (4) religijny - związany z relacjami z Bogiem, np. poczucie bliskości Boga, doświadczenie religijne ${ }^{24}$. W przypadku, gdy dany cel jest znaczący dla jednostki, stanowi on istotną wartość z indywidualnej perspektywy. Jednostka będzie wówczas dążyć do osiągnięcia tego celu, widząc w tym głębszy sens.

Podkreślić należy, że znaczenie nie jest koniecznym ani wyjątkowym elementem religii. Pojęcie znaczenia występuje również w niereligijnym kontekście, np. osoby uznają za znaczące i ważne wydarzenia, takie jak ślub, rodzina, praca lub urodzenie dziecka. Dany element nabiera znaczenia religijnego tylko wtedy, gdy posiada charakter sacrum lub gdy związany jest ze świętością ${ }^{25}$. Oznacza to, że dane

${ }^{21}$ Por. L. A. Kirkpatrick, An Emerging New Foundation for the Psychology of Religion, [w:] Handbook of the Psychology of Religion and Spirituality, s. 111.

${ }_{22}$ Por. M. R. Levenson, C. M. Aldwin, M. D’Mello, Religious Development from Adolescence to Middle Adulthood, [w:] Handbook of the Psychology of Religion and Spirituality, s. 145; E. C. Roehlkepartain, P. L. Benson, P. E. King, L. M. Wagener, Spiritual Development in Childhood and Adolescence: Moving to the Scientific Mainstream, [w:] The Handbook of Spiritual Development in Childhood and Adolescence, red. E. C. Roehlkepartain, P. E. King, L. Wagener, Thousand Oaks 2005, s. 8-9.

${ }^{23}$ Por. P. C. Hill, K. I. Pargament, Advances in the Conceptualization and Measurement of Religion and Spirituality, „American Psychologist” $58: 2003$, nr 1, s. 65.

${ }^{24}$ Por. B. J. Zinnbauer, K. I. Pargament, Religiousness and Spirituality, s. 24.

${ }^{25}$ Por. K. I. Pargament, The Psychology of Religion..., s. 32. 
doświadczenie staje się religijnym, gdy sfera sacrum zostaje włączona w aspiracje i reakcje jednostki. Jako przykład można podać ślub, który może mieć charakter wyłącznie świecki - wówczas posiada znaczenie niereligijne. Osoby mogą jednak zawrzeć ślub kościelny, który na skutek związku ze sferą świętości (ceremonia udzielenia błogosławieństwa Bożego) nabiera religijnego charakteru i charakterystycznego znaczenia w kategoriach sacrum. Poszukiwanie znaczenia stanowi istotny punkt $\mathrm{w}$ religijności i duchowości, ponieważ wskazuje na ważność sfery sacrum dla indywidualnego i społecznego funkcjonowania człowieka.

Badania z dziedziny psychologii religii pokazują, że proces uświęcania (sanctification), czyli przyjmowania przez dane zdarzenie charakteru świętości, ma bardzo ważne znaczenie dla funkcjonowania jednostek. Spostrzeganie różnych aspektów życia w perspektywie świętości okazało się istotne w takich sferach, jak małżeństwo $^{26}$, sfery życia przedmałżeńskiego ${ }^{27}$ i główne dążenia życiowe ${ }^{28}$. Nabieranie znaczenia na skutek uświęcania wynika z kilku przyczyn. Po pierwsze, osoby wykazują skłonności do inwestowania większej ilości czasu w sfery życia uważane za święte. Konsekwencją będzie większa ważność tych sfer. Po drugie, w sytuacji spostrzegania aspektów swojego życia w kategoriach świętości osoby liczą na pomoc i opiekę Sił Wyższych, co dostarcza psychicznego wsparcia i poczucia większej efektywności działania. Po trzecie, proces uświęcania wzbudza pozytywne emocje, które okazują się istotnym zasobem psychicznym w codziennym życiu ${ }^{29}$. Powyższe przyczyny wyjaśniają, dlaczego włączenie danego doświadczenia w kategorię świętości powoduje zwiększenie znaczenia z perspektywy konkretnej jednostki. Sfera świętości powoduje spostrzeganie doświadczeń przez pryzmat religijny, który „włącza” je w szerszy, uniwersalny kontekst.

Proces uświęcania rozumiany w szerszym ujęciu może reprezentować poszukiwanie świętości przez jednostkę. Wynika to z faktu, że osoba stara się znaleźć głębszy, religijny lub duchowy sens zdarzeń i rzeczy. Innymi słowy, dąży ona do odkrycia powiązań konkretnych elementów życia ze sferą sacrum, dzięki czemu nabierają one charakteru świętości. W wielu sytuacjach codziennego życia obecność sacrum nie jest wyraźnie widoczna. Poza sytuacjami typowo religijnymi, zachodzącymi w kontekście kościoła czy uroczystości religijnych, człowiek zmuszony jest

${ }^{26}$ Por. A. Mahoney, K. I. Pargament, T. Jewell, A. B. Swank, E. Scott, E. Emery, M. Rye, Marriage and the Spiritual Realm: The Role of Proximal and Distal Religious Constructs in Marital Functioning, „Journal of Family Psychology” 13 : 1999, s. 15-16.

${ }^{27}$ Por. N. A. Murray-Swank, K. I. Pargament, A. Mahoney, At the Crossroads of Sexuality and Spirituality: The Sanctification of Sex by College Students, ,The International Journal for the Psychology of Religion" $15: 2005$, nr 3, s. 216.

${ }^{28}$ Por. A. Mahoney, K. I. Pargament, B. Cole, T. Jewell, G. M. Magyar, A Higher Purpose: The Sanctification of Strivings in a Community Sample, „International Journal for the Psychology of Religion" $15: 2005, \mathrm{nr} 3$, s. 259-260.

${ }^{29}$ Por. A. Mahoney, N. Tarakeshwar, Religion's Role in Marriage and Parenting in Daily Life and During Family Crises, [w:] Handbook of the Psychology of Religion and Spirituality, s. 188. 
poszukiwać i odkrywać sacrum. Jest to proces wymagający wysiłku i zaangażowania poznawczego, gdyż sfera sacrum jest często „wtopiona” w rzeczywistość i wymaga uświadomienia sobie jej istnienia. Uprawomocnione wydaje się zatem stwierdzenie, że proces uświęcania należy traktować jako przejaw poszukiwania sacrum w otaczającym świecie.

Jeśli przyjmiemy pogląd wyrażany przez wielu psychologów, że zarówno religijność, jak i duchowość jest poszukiwaniem świętości (search for the sacred), to pojawia się pytanie, w jakich wymiarach życia można odkrywać świętość ${ }^{30}$. Jak zauważono wcześniej, pierwotnym i podstawowym wymiarem jest kontekst ściśle religijny i duchowy: kościół, świątynia, uroczystości religijne oraz aktywność własna (modlitwa, medytacja, kontemplacja). W ramach tych miejsc i aktywności osoba stara się nawiązać relacje z Bogiem, aby doświadczyć tajemnicy sacrum i przeżyć doświadczenie wiary ${ }^{31}$. Jakość relacji z Bogiem zależeć będzie od rozwoju religijnego i duchowego jednostki, a także rodzaju aktywności religijnych i duchowych, w których ona uczestniczy. W tym przypadku możemy mówić o bezpośrednim dążeniu do odkrycia sacrum.

Poszukiwanie sacrum może posiadać pośredni charakter, który uwidacznia się wtedy, gdy przedmiotem eksploracji jest otaczający świat. Nie chodzi tutaj o traktowanie rzeczy czy zdarzeń w kategoriach nadprzyrodzonych, gdyż w tym przypadku zahaczalibyśmy o panteizm, lecz raczej o spostrzeganie tych obiektów jako będących w pewnej relacji do świętości. Funkcję taką mogą spełniać czynności religijne (sakramenty) i przedmioty kultu religijnego (krzyż, szaty liturgiczne), które na skutek uświęcenia nabierają szczególnego charakteru i wartości dla osoby wierzącej.

Inne aspekty życia również mogą zostać powiązane ze sferą świętości. Można tutaj zaliczyć: zdrowie - traktowanie ciała jako ,świątyni Boga” w chrześcijaństwie lub szacunek dla życia w buddyzmie; ludzie - kult świętych, cześć oddawana liderom ruchów i wyznań religijnych; atrybuty i relacje społeczne - przykładem mogą być cnoty związane blisko z religią, takie jak współczucie, a także patriotyzm i odpowiedzialność za wspólnotę; wytwory kultury - w tym zakresie wymienić można wielkie dzieła muzyki czy malarstwa oparte na inspiracjach religijnych ${ }^{32}$. Charakterystyczną cechą uświęconych aspektów życia jest to, że wskazują na coś, co wykracza poza ich normalne rozumienie. Poprzez związek ze sferą świętości stają się symbolami reprezentującymi głębszą, ostateczną rzeczywistość.

Kolejnym ważnym zagadnieniem jest określenie, czy poszukiwanie sacrum będzie posiadało odmienny charakter w ramach religijności i duchowości. Pytanie

${ }^{30}$ Por. W. R. Miller, C. E. Thoresen, Spirituality, Religion, and Health: An Emerging Research Field, „American Psychologist” 58 : 2003, s. 27; K. I. Pargament, The Psychology of Religion ..., s. 34.

${ }^{31}$ Por. B. Spilka, R. W. Hood, B. Hunsberger, R. Gorsuch, The Psychology of Religion. An Empirical Approach, New York 2003, s. 280-281.

${ }^{32}$ Por. K. I. Pargament, A. Mahoney, Sacred Matters: Sanctification as a Vital Topic for the Psychology of Religion, „The International Journal for the Psychology of Religion” 15 : 2005, nr 3, s. 185-186. 
to wydaje się całkowicie uzasadnione, gdyż - jak podkreślono wcześniej - religijność jest złączona z konkretnym wyznaniem, posiada instytucjonalny charakter i związek z określoną tradycją, natomiast duchowość odnosi się bardziej do indywidualnej, globalnej aktywności poszukiwania świętości w świecie (ludzie, środowisko przyrody, kosmos).

Uwzględniając istniejące różnice, można pokusić się o wymienienie trzech głównych cech różnicujących dążenie do odkrywania świętości w ramach obydwóch fenomenów.

(1) Poszukiwanie świętości w religijności będzie posiadało charakter raczej instytucjonalny i skodyfikowany, oparty na ustalonych normach i standardach. Przy duchowości będziemy mieli do czynienia z formami poszukiwania świętości bazującymi na osobistym, wolnym wyborze, który nie jest ograniczony zewnętrznymi wskazaniami.

(2) W przypadku religijności mamy do czynienia zarówno z indywidualnym, jak i wspólnotowym charakterem. Oznacza to, że osoby rozwijają i formują swoje życie religijne na podstawie doświadczeń osobistych (indywidualna modlitwa lub medytacja) oraz wspólnotowych (udział w nabożeństwach, przynależność do wspólnoty). Jeśli chodzi o duchowość, to dominującą cechą będzie indywidualny charakter, wyrażający się we własnym, prywatnym pogłębianiu życia duchowego i przeżywaniu osobistych doświadczeńn ${ }^{33}$.

(3) Ostatnią istotną różnicą będzie kryterium rozwoju, które przy religijności będzie posiadało zewnętrzny charakter, natomiast przy duchowości - wewnętrzny. Wyznacznikiem rozwoju religijnego będą przede wszystkim wskazania instytucji kościelnych i wyznaniowych, takie jak święte księgi wielkich religii (Biblia, Koran, Wedy), nauczanie przywódców religijnych oraz uznawanie prezentowanych prawd wiary. W tym przypadku akcent będzie położony na zewnętrznym autorytecie ${ }^{34}$. W ramach duchowości wyznacznikiem rozwoju będą indywidualne potrzeby duchowe jednostek, których zaspakajanie odbywać się będzie na drodze osobistych wyborów i decyzji. Duchowość będzie wyrażać uniwersalne ludzkie dążenia do doświadczenia transcendencji, niekoniecznie w ramach tradycyjnych religii ${ }^{35}$. Akcent spoczywać będzie tutaj na wewnętrznym autorytecie, bazującym na własnych poglądach i przekonaniach.

Zaznaczyć należy, że powyższe cechy odnoszą się do duchowości prezentowanej na gruncie współczesnej psychologii religii i jako takie nie oddają wszystkich możliwych form życia duchowego. W ramach tradycyjnych religii można bowiem spotkać wiele rodzajów czy form duchowości, które doskonale funkcjonują w obrębie instytucji,

${ }^{33}$ Por. B. J. Zinnbauer, K. I. Pargament, Religiousness and Spirituality ..., s. 35.

${ }^{34}$ Por. S. Tokarski, Dojrzałość religijna, [w:] Podstawowe zagadnienia psychologii religii, red. S. Głaz, Kraków 2006, s. 168-170.

${ }^{35}$ Por. R. L. Piedmont, Cross-Cultural Generalizability of the Spiritual Transcendence Scale to the Philippines: Spirituality as a Human Universal, „Mental Health, Religion and Culture” 10 : 2007 , nr 2, s. 90-91. 
wyznawanych prawd i wspólnoty wierzących. Przy naszym opisie koncentrowaliśmy się raczej na współczesnych, psychologicznych trendach duchowości.

\section{Czynniki warunkujące poszukiwanie sacrum W religijności i duchowości}

Ważnym aspektem badań nad poszukiwaniem sacrum w religijności i duchowości jest określenie czynników, które wpływają na ten proces i determinują jego przebieg. Wymienienie wszystkich czynników odgrywających rolę nie jest łatwe, gdyż mamy do czynienia ze złożonymi fenomenami, odnoszącymi się do związków z transcendencją. Niemniej, uwzględniając osiągnięcia psychologii religii, można wymienić cztery podstawowe czynniki warunkujące poszukiwanie sacrum w religijności i duchowości: okres rozwojowy, kultura i wychowanie, zdarzenia życiowe, aktywność własna.

(1) Okres rozwojowy - refleksja teoretyczna i wyniki badań empirycznych jednoznacznie wskazują, że życie religijne i duchowe człowieka podlega nieustannemu rozwojowi i doskonaleniu się ${ }^{36}$. Religijność posiada swoją własną strukturę i rozwija się według własnych praw. Struktura religijności jednostki na poszczególnych etapach rozwoju, począwszy od okresu wczesnodziecięcego, poprzez adolescencję i dorosłość, na starości skończywszy, ulega przemianom, ujawniając coraz to nowe charakterystyczne cechy i sposoby reagowania na sferę sacrum. Jak podkreśla $\mathrm{C}$. Walesa, jest to związane ze zmianą myślenia, emocji i uczuć oraz stylów reagowania, co prowadzi do wykształcania się specyficznych form religijności ${ }^{37}$. Konsekwencją jest zmiana wrażliwości człowieka na zdolność ujmowania sacrum, kształtowanie i podejmowanie relacji do sfery sacrum, jego rozumienie i wyrażanie w kategoriach czysto ludzkich.

Poszukiwanie sacrum w poszczególnych okresach rozwojowych będzie się różnić w odniesieniu do religijności i duchowości, co wynika z innego sposobu rozumienia obydwóch fenomenów. Rozwój religijny może być określony jako rozwój dziecka w ramach ustrukturowanej społeczności, która posiada wspólne praktyki, nauki, rytuały i symbole, wykorzystywane dla przybliżenia ludzi do sfery sacrum i wzmocnienia relacji społecznych ${ }^{38}$. Poszukiwanie sacrum w ramach religijności będzie wyrażać się w stopniowym pogłębianiu relacji do sfery transcendentnej poprzez poznawanie symboli religijnych danej religii, wzrastaniu zgodnym z normami i wskazaniami tradycji, nabywaniu informacji religijnych, a także pogłębianiu wiary w oparciu o kult i rytuały religijne.

${ }^{36}$ Por. Ch. J. Boyatzis, Religious and Spiritual Development in Childhood, [w:] Handbook of the Psychology of Religion and Spirituality, s. 123.

${ }^{37}$ Por. C. Walesa, Rozwój religijności człowieka, [w:] Podstawowe zagadnienia psychologii religii, s. $111-112$.

${ }^{38}$ Por. Ch. J. Boyatzis, Religious and Spiritual..., s. 125. 
Rozwój duchowy jest ujmowany jako proces wzrostu wewnętrznej ludzkiej zdolności dla samotranscendencji, w której ja jest zakorzenione lub ukierunkowane na świętość ${ }^{39}$. Z tej perspektyw rozwój poszukiwania sacrum $\mathrm{w}$ duchowości będzie opierał się na indywidualnym pogłębianiu umiejętności zrozumienia własnego ja w relacji do sfery świętości, dążeniu do odkrywania przejawów sacrum w otaczającym świecie i próbach harmonijnego wspótistnienia z innymi osobami.

(2) Kultura i wychowanie - zarówno religijność, jak i duchowość są zjawiskami dynamicznymi, podlegającymi zmianom w zakresie swoich treści oraz form. Istotny wpływ na różnice między rodzajami religijności i duchowości posiadają kultura i wychowanie jednostek dokonujące się w ramach tej kultury, co wynika ze ścisłego związku kultury i religii ${ }^{40}$. Kultura obejmuje szereg wzorców i norm, świadomie i celowo ukształtowanych przez człowieka oraz zespół myśli, idei i wartości, akceptowanych przez grupy ludzi. Religijność i duchowość nie mogą rozwijać się w ,pustce”, wręcz przeciwnie - podlegają oddziaływaniu wzorców kulturowych i społecznych, a także oddziaływaniom wychowawczym.

Z punktu widzenia psychologii międzykulturowej można mówić o społecznych i kulturowych uwarunkowaniach religijności i duchowości. Kultura stanowi swoistą bazę dla religijności i duchowości poprzez idee i wartości, na których można kształtować wrażliwość, symbolikę i zachowanie w relacji do sacrum. H. Grzymała-Moszczyńska trafnie zauważa, że kultura staje się ważną kategorią, wyjaśniającą sposób myślenia i doświadczania religii przez jednostkę i grupę $e^{41}$. Staje się to wyraźnie widoczne, gdy weźmiemy pod uwagę różnice kulturowe między Zachodem a Wschodem oraz religie, które powstały w tych kulturach, tj. z jednej strony - chrześcijaństwo i judaizm, a z drugiej - hinduizm i buddyzm.

Uważne spojrzenie na wymienione kultury i religie ujawnia szereg powiązań, ukształtowanych w perspektywie wielu lat wzajemnego przenikania się treści kulturowych i religijnych. Praktycznie, zdecydowana większość treści stanowiących przedmiot religii, tj. praktyki religijne i duchowe, pojęcie Boga, formy kultu, przekonania o losie człowieka po śmierci, jest „zanurzona” w kontekście kulturowym, który specyfikuje wyznawaną religię ${ }^{42}$. Związek z kulturą i wychowaniem będzie większy w przypadku religijności niż duchowości, co wynika z bardziej wszechstronnych powiązań instytucjonalnych i tradycyjnych religii niż form duchowości mających głównie osobisty charakter.

(3) Zdarzenia życiowe - religijność i duchowość uwarunkowane są nie tylko czynnikami zewnętrznymi (kultura, społeczeństwo), ale i szeregiem czynników wewnętrznych, związanych z konkretnymi jednostkami (doświadczenia indywidualne).

${ }^{39}$ Por. D. Krok, Religijność a duchowość - różnice i podobieństwa z perspektywy psychologii religii, „Polskie Forum Psychologiczne” 14 : 2009, nr 1, s. 129.

${ }^{40}$ Por. Z. Zdybicka, Religia i religioznawstwo, Lublin 1992, s. 143.

${ }^{41}$ Por. H. Grzymała-Moszczyńska, Religia a kultura ..., s. 11.

${ }^{42}$ Por. D. Fontana, Psychology, Religion..., s. 44-45. 
Zdarzenia występujące w różnych okresach życia modyfikują religijność i duchowość poprzez zmianę schematów myślenia, restrukturyzację dotychczasowych stylów rozumowania, regulację emocji oraz korektę zachowań ${ }^{43}$. Trudno w krótkim artykule podać wszystkie potencjalne zdarzenia życiowe odgrywające rolę w kształtowaniu religijności i duchowości. Można jednak pokusić się o wymienienie najbardziej reprezentatywnych form.

Trafnym przykładem jest zagadnienie kryzysów religijnych, silnie wpływające na religijność i duchowość jednostek. Kryzys religijny jest przykrym emocjonalnie stanem wewnętrznego napięcia, który ściśle wiąże się z mniejszą lub większą dezintegracją życia religijnego ${ }^{44}$. Wydarzenie to posiada dynamiczny charakter, wyrażający się krytycznym nastawieniem do aprobowanych dotychczas treści i form religijnych i tendencją do licznych zmian w tej dziedzinie. Konsekwencją są działania zmierzające do wewnętrznej przemiany religijnej, która może zmierzać w dwóch zasadniczych kierunkach: pozytywnym - jednostka ugruntowuje swoją religijność, oraz negatywnym - człowiek odwraca się od religii i przyjmuje postawę niechętną lub obojętną.

Innymi przykładami zdarzeń życiowych wpływających na poszukiwanie sacrum przez jednostkę mogą być: negatywne doświadczenia ze skrajnymi formami religijności i duchowości, np. fundamentalizmem religijnym, śmierć bliskiej osoby powodująca wstrząs psychiczny i naruszająca dotychczasowe poglądy na Bożą sprawiedliwość, nagłe nawrócenia reorganizujące wcześniejsze myślenie i zachowanie człowieka, kontakt z ruchami religijnymi stymulujący religijną i duchową aktywność, a także poważna choroba zmieniająca perspektywę życia. Wymienione zdarzenia, szczególnie jeśli są nagłe i silnie nacechowane emocjonalnie, potrafią modyfikować formy poszukiwania sacrum.

(4) Aktywność własna - w sferze religijnej i duchowej sacrum nie jest bezpośrednio dostępne, co wynika z rozgraniczenia rzeczywistości dostępnej poznaniu empirycznemu (świat, procesy psychiczne) i pozaempirycznemu (transcendencja, Bóg). Poszukiwanie sacrum wymaga zatem aktywności człowieka, który podejmując działania eksploracyjne, coraz bardziej odkrywa tajemnicę transcendencji i pogłębia relacje do niej. Stanowisko to bazuje na przekonaniu, że jednostka może stawać się sprawcą, a nie tylko biernym uczestnikiem „dramatu życia”"45. Aktywność własna przejawiająca się w zdobywaniu nowych informacji, podejmowaniu trudnych wyzwań oraz inicjowaniu działań zmierzających do odkrywania nieznanych dotychczas treści natury religijno-duchowej zmienia perspektywę wiary i umożliwia formowanie dojrzałej religijności i duchowości.

Takie formy aktywności, jak modlitwa czy medytacja, podejmowane przez dłuższy okres czasu, prowadzą do wzrostu religijności i duchowości, a także szeregu

${ }^{43}$ Por. B. Grom, Psychologia religii, Kraków 2009, s. 203.

${ }^{44}$ Por. F. Głód, Kryzys religijny, [w:] Podstawowe zagadnienia psychologii religii, s. 183.

${ }^{45}$ J. Kozielecki, Człowiek wielowymiarowy, Warszawa 2001, s. 41. 
pozytywnych konsekwencji psychicznych, np. wzrostu równowagi psychicznej, większej akceptacji uczuć, obniżenia poziomu lęku ${ }^{46}$. Określone formy własnej aktywności, poprzez stymulację życia religijnego i duchowego, przyczyniają się do zwiększenia skuteczności zachowań ukierunkowanych na poszukiwanie sacrum. Świadoma aktywność jednostek na płaszczyźnie poznawczej (myślenie, rozumowanie) i behawioralnej (zachowania i działania), a związana ze sferą sacrum umożliwia formowanie nowych sposobów odkrywania przejawów świętości w świecie i lepszego rozumienia własnych relacji do Boga.

W podsumowaniu artykułu należy stwierdzić, że poszukiwanie sacrum należy do podstawowych funkcji zarówno religijności, jak i duchowości. Chosiaż obydwa fenomeny różnią się z punktu widzenia współczesnej psychologii religii, wykazują wiele cech wspólnych. Pierwszorzędnym wskaźnikiem łączącym religijność i duchowość jest sfera sacrum i dążenie do niej. Poszukiwanie sacrum ma dynamiczny charakter, wyrażający się w permanentnym, zmieniającym się odkrywaniu znaczenia w osobistym i społecznym życiu jednostki. W procesie tym człowiek stara się modyfikować swoje relacje z Bogiem oraz odnajdywać przejawy świętości w otaczającej rzeczywistości. Z punktu widzenia psychologii religii poszukiwanie sacrum jest niekończącym się działaniem, determinowanym w dużej części przez cztery czynniki: okres rozwojowy, kulturę i wychowanie, zdarzenia życiowe i aktywność własną, których konstelacja w umyśle jednostki wyrażać będzie charakterystyczne rozumienie świętości.

\section{Summary}

\section{The psychological conception of searching for sacrum in religiousness and spirituality}

Nowadays, there is a growing interest in the area of psychology of religion as regards religiousness and spirituality. In the past both terms overlapped substantially which was clearly visible in great spiritual traditions of many religions. Recently, however, spirituality has emerged as a distinct construct. Although, religiousness and spirituality have common characteristics they are generally regarded as related but not identical constructs. Both religiousness and spirituality are embedded within the context of "a search for the sacred" which refers to sacrum. The main difference is that religiousness represents the personal or communal search for the sacred that happens within a traditional and institutionalized context, while spirituality is usually understood as a search for the sacred at the level of the individual. The process of "search" entails the attempt to discover significance. People are goal-directed beings who pursue whatever they hold significant in their lives. The search for sacrum lies in the heart of religiousness and spirituality and can be found at multiple level of analysis: psychological, social, physical, and material. There are four main factors that determine the search for

${ }^{46}$ Por. D. Krok, Medytacja, [w:] Podstawowe zagadnienia psychologii religii, s. 369; B. Spilka, R. W. Hood, B. Hunsberger, R. Gorsuch, The Psychology of Religion ..., s. 489-490. 
sacrum: developmental stage, culture and upbringing, life events, and activity. Their levels specify one's religiousness and spirituality.

\section{Keywords}

Religiousness, search for the sacred, spirituality 
